\title{
Mode of Action of Benzyladenine When Used as a Chemical Thinner on Apples
}

\author{
Duane W. Greene, Wesley R. Autio, Jeffrey A. Erf, and Zhongyuan Y. Mao \\ Department of Plant and Soil Sciences, University of Massachusetts, Amherst, MA 01003
}

Additional index words. Malus domestica, cytokinin, 6-benzylaminopurine, BA, fruit thinning, fruit set, fruit quality, foliar penetration

\begin{abstract}
BA thinned apple (Malus domestica Borkh.) fruits when applied to either the leaves or the fruit, although it was much more effective when applied to the leaves. BA increased fruit size independent of its effects on reducing crop load, but only when applied directly to the fruit. When applied to one of two fruit in a cluster, BA had no influence on abscission, fruit size, or fruit characteristics of the adjacent nontreated fruit. BA reduced fruit flesh Ca only on treated fruit and the response was inversely proportional to the increase in fruit size. More than $60 \%$ of the BA applied to a fruit was absorbed during 24 hours, and this amount was considerably larger than penetration through either the abaxial or adaxial leaf surface. BA treatments that thinned also increased ethylene production linearly in both leaves and fruit 24 hours after application, but the magnitude of increase was not considered large enough to be the primary cause for thinning. BA thinned spurs with two or three fruit more than spurs with one fruit, and it did not selectively thin to just one fruit per cluster. Chemical name used: N-(phenylmethyl)-1H-purine6-amine [benzyladenine (BA)].
\end{abstract}

One of the most important practices in modern apple production is the reduction in crop load to a level that will assure acceptable fruit size and allow adequate return bloom (Looney, 1986; Miller, 1986; Williams and Edgerton, 1981). Carbaryl and naphtholeneacetic acid (NAA) are the thinning chemicals most frequently used (Jonkers, 1979; Southwick, 1968). Although effective, ethephon is used only in areas where adequate thinning results are difficult to achieve using the other chemical thinners (Jonkers, 1979; Jones et al., 1983; Unrath, 1978). McLaughlin and Greene (1984) first suggested that BA might be a good chemical thinner for apples. Subsequent reports have confirmed the effectiveness of BA as a thinner on 'McIntosh' (Greene and Autio, 1989), 'Idared' (Elfving, 1989), 'Empire' (Elfving, 1991; Greene et al., 1990), and 'Delicious' (Greene et al., 1990). BA appears to have several advantages over the other commonly used chemical thinners: it may increase fruit size in addition to that attributed to reduced crop load, it is unlikely to have adverse effects on beneficial mite predators, and it does not cause severe epinasty. However, little is known about how BA acts as a chemical thinning agent and the chances of official approval for such use is unknown.

The purpose of this investigation was to explore several factors that may cause fruit abscission when BA is used as a chemical thinner on apples.

\section{Materials and Methods}

All trees used in this investigation were mature, bearing 'McIntosh' growing at the Univ. of Massachusetts Horticultural Research Center, Belchertown.

Site of absorption. Nine trees in a block of mature 'Rogers McIntosh'/M.26 were selected. Forty spurs with two 12-mm fruit and comparable leaf area were individually tagged. Only leaves on one group of 10 spurs were sprayed to the drip point with BA at $100 \mathrm{mg} \cdot$ liter $^{-1}$. Fruit was sprayed on another group of 10 spurs, and both leaves and fruit were sprayed with BA on

Received for publication 26 Aug. 1991. Accepted for publication 11 Mar. 1992. Paper no. 3027, Massachusetts Agr. Expt. Sta., Univ. of Massachusetts, Amherst. This research was supported in part by Experiment Station Project no. 609 . The cost of publishing this paper was defrayed in part by the payment of page charges. Under postal regulations, this paper therefore must be hereby marked advertisement solely to indicate this fact. a third group of 10 spurs. Fruit and leaves on the fourth group of spurs were not sprayed and served as a control. Each tree was considered a replication. The number of fruit persisting on each tagged spur was counted at the end of June drop in July. At the normal harvest time in September, the fruit from all tagged spurs were harvested and weighed. Flesh firmness was determined on two sides of each fruit using an Effegi penetrometer (Facchini, Alfonsine, Italy) equipped with an 11-mm tip. The soluble solids content (SSC) of a composite sample of juice collected from the penetrometer test was determined using a hand-held refractometer. Each fruit was then cut open, and the number of viable seeds was counted.

${ }^{14} \mathrm{C}$-labeled BA penetration. Twelve groups of three spurs were tagged on mature 'Rogers McIntosh'/M.9/MM.111 trees and hand thinned to two fruit per spur. When fruit were $12 \mathrm{~mm}$ in diameter, a circle $2 \mathrm{~cm}$ in diameter was outlined with dots of India ink on the abaxial or adaxial surface of one leaf on one spur per group. Ten $0.22 \mu \mathrm{l}$ droplets of ${ }^{14} \mathrm{C}$-labeled BA (total of 30,000 cpm) were applied within the marked area on one leaf either to the adaxial or abaxial surface of the leaf or to the upper exposed surface of one fruit per spur. The ${ }^{14} \mathrm{C}$-labeled BA solution contained $25 \mathrm{mg} \mathrm{BA} / \mathrm{liter}$ and was buffered at $\mathrm{pH}$ 7.0 with citrate-phosphate buffer in $0.01 \%$ X-77 surfactant. After $24 \mathrm{~h}$, each spur was harvested and taken to the laboratory where the $2 \mathrm{~cm}$ marked and treated area was removed from each leaf and the treated fruit removed from the spur. The fruit or treated leaf disks were each rinsed with $10 \mathrm{ml}$ of $75 \%$ acetone : $25 \%$ water containing $0.1 \%$ X-77 surfactant. One milliliter of the 10 $\mathrm{ml}$ rinse was placed in a scintillation vial containing $10 \mathrm{ml}$ of Ecolume scintillation cocktail (ICN Biomedical, Irvine, Calif.). Leaf disks and fruit were oxidized for $3 \mathrm{~min}$ in a biological material oxidizer (Model 0X-400; Harvey Instrument Corp., Hillside, N.J.). Evolved ${ }^{14} \mathrm{CO}_{2}$ was collected in an external trap containing $15 \mathrm{ml}$ of Harvey ${ }^{14} \mathrm{C}$ cocktail. Radioactivity was determined in washes and oxidized tissue by use of a liquid scintillation counter. Counts were adjusted to account for quenching and for biological oxidizer efficiency; uptake was calculated as the percent of total ${ }^{14} \mathrm{C}$-labeled BA applied.

Ethyleneproduction, fruit thinning, and fruit size. Five limbs, 12 to $15 \mathrm{~cm}$ in circumference, were selected and tagged on six mature 'McIntosh' trees before bloom. All blossom clusters were counted on the tagged portion of each limb at the pink stage of 
blossom development. On 2 June, when fruit were $11 \mathrm{~cm}$ in diameter, one limb on each tree was sprayed to the drip point with 50,100 , or $150 \mathrm{mg} \mathrm{BA} /$ liter. The fourth limb was not sprayed and the fifth limb on each tree was sprayed with 7.5 mg NAA/liter. One day after application, 15 spur leaves and 20 fruit were collected from each limb. The leaves and the fruit were placed in separate $125-\mathrm{ml}$ Erlenmeyer flasks. Three hours after serum caps had been attached, a 1-ml gas sample was taken and ethylene was determined by gas chromatography, and the amount of ethylene evolved per unit weight of tissue was calculated. The total number of fruit persisting on each tagged limb was counted in July. At the normal harvest date, 30 fruit were harvested from each limb and weighed.

Droplet application. Twenty spurs each bearing $10-\mathrm{mm}$ diameter fruit were tagged on each of 10 mature 'McIntosh'/M.9/ MM.111 trees. One fruit on each spur was tagged. The nontagged fruit on 10 spurs were treated with BA at 100 mg-liter-1, and this treatment was repeated 8 days later with BA at 125 mg-liter-'. Fruit on the remaining 10 spurs received no treatment. Persisting fruit on each spur were counted in July. At the normal harvest time, each fruit was marked with an indelible marker and its weight, flesh firmness, SSC, and seed count were determined. A $1-\mathrm{cm}$ slice was taken from the equator of each fruit and a 13-mm diameter plug was taken from four quadrants of the slice just below the peel. The nutrient content of the tissue plugs was determined according to the methods of Weis et al. (1980).

Fruit density. Eighteen mature 'McIntosh'/M.9/MM.111 were paired into nine blocks (replications) of two trees each according to proximity and crop load. Ten spurs each bearing either one, two, or three fruit 10 to $12 \mathrm{~mm}$ in diameter were tagged per tree (30 spurs total per tree). One tree in each group was sprayed to the drip point with $100 \mathrm{mg}$ BA/liter. Fruit set was determined on each tagged spur at 3- to 6-day intervals for 27 days and again in late July. At the normal harvest, fruit from each spur. were individually identified, harvested, and fruit characteristics quantified as described. previously.

Statistical analysis. Analysis of variance was used in all experiments to determine significance and, where appropriate, orthogonal polynomial comparisons were made. Where appropriate, treatment means were separated by Duncan's new multiple range test $(P=0.05)$.

\section{Results}

Site of absorption. BA thinned fruit regardless of the site of application (Table 1). However, BA appeared to be most effective when applied to the leaves, since more fruit abscised when leaves only were sprayed than when fruit only were sprayed. Application to leaves and fruit was no more effective than application to leaves alone. BA increased fruit size and reduced seed count only when BA was applied directly to the fruit.

${ }^{14} C$-labeled BA penetration. A considerably higher percent of the applied BA entered the fruit than entered the leaves (Table 2). Penetration into leaves was greater through the abaxial than through the adaxial surface.

Ethylene production, thinning, and fruit size. BA caused fruit thinning, increased fruit weight, and slightly elevated ethylene production in fruit and leaves (Table 3). NAA thinned more effectively than BA, but BA increased fruit size whereas NAA did not. While both NAA and BA increased ethylene production, the effect of BA was more pronounced in the fruit.

Droplet application. Application of BA to individual fruit did not increase fruit abscission. BA increased fruit weight only
Table 1. Effects of site of BA application on fruit set and fruit characteristics of 'McIntosh' apples.

\begin{tabular}{lccccc}
\hline \hline & & & \multicolumn{3}{c}{$\begin{array}{c}\text { Soluble } \\
\text { solids }\end{array}$} \\
$\begin{array}{l}\text { Site of BA } \\
\text { application }\end{array}$ & $\begin{array}{c}\text { Fruit } \\
\text { Fruit per }^{2}\end{array}$ & $\begin{array}{c}\text { Flesh } \\
\text { cluster }^{z} \\
(\mathrm{~g})\end{array}$ & $\begin{array}{c}\text { firmness } \\
(\mathrm{g})\end{array}$ & $\begin{array}{c}\text { concn } \\
(\%)\end{array}$ & $\begin{array}{c}\text { Seed } \\
\text { count }^{2}\end{array}$ \\
\hline Control & 1.67 & 145 & 70.6 & 10.7 & 6.9 \\
Leaves only & 0.99 & 147 & 72.0 & 10.8 & 6.4 \\
Fruit only & 1.23 & 169 & 69.7 & 10.7 & 5.6 \\
Leaves and fruit & 1.04 & 169 & 68.8 & 10.8 & 5.5 \\
Significance & & & & & \\
$\quad$ Leaves & $* *$ & NS & NS & NS & NS \\
$\quad$ Fruit & NS & $* *$ & $*$ & NS & $*$ \\
$\quad$ Leaves and fruit & $*$ & NS & NS & NS & NS \\
$\quad$ Fruit without leaves & $* *$ & --- & --- & --- & --- \\
$\quad$ Fruit with leaves & NS & --- & -- & --- & --- \\
\hline
\end{tabular}

${ }^{2}$ Mean of 90 observations.

'Mean of nine observations.

$* *,{ }^{\text {Ns }}$ Significant at $P=0.01,0.05$, or nonsignificant, respectively.

Table 2. Penetration of ${ }^{14} \mathrm{C}-\mathrm{BA}$ into fruit and spur leaves of ' $\mathrm{Mc}$ Intosh' apples. ${ }^{\text {z,y }}$

\begin{tabular}{|c|c|c|}
\hline \multirow[b]{2}{*}{ Plant surface treated } & \multicolumn{2}{|c|}{$\begin{array}{c}\text { Uptake after } 24 \mathrm{~h} \\
\text { (\% of }{ }^{14} \mathrm{C}-\mathrm{BA} \text { applied) }\end{array}$} \\
\hline & 1989 & 1990 \\
\hline $\begin{array}{l}\text { Fruit } \\
\text { Leaf abaxial side } \\
\text { Leaf adaxial side } \\
\end{array}$ & $\begin{array}{r}66.7 \mathrm{a} \\
35.1 \mathrm{~b} \\
5.4 \mathrm{c}\end{array}$ & $\begin{array}{r}60.4 \mathrm{a} \\
9.1 \mathrm{~b} \\
5.7 \mathrm{c}\end{array}$ \\
\hline
\end{tabular}

${ }^{2}$ Mean of 12 observations.

'Mean separation in columns by Duncan's new multiple range test, $P$ $=0.05$.

Table 3. Effect of BA and NAA on fruit set, fruit weight, and ethylene production of 'McIntosh' apples.'

\begin{tabular}{|c|c|c|c|c|c|}
\hline \multirow[b]{2}{*}{ Chemical $^{z}$} & \multirow{2}{*}{$\begin{array}{c}\text { Concn } \\
\left(\mathrm{mg} \cdot \text { liter }^{-1}\right)\end{array}$} & \multirow{2}{*}{$\begin{array}{c}\text { Fruit per } \\
\text { cm limb } \\
\mathrm{x} \text {-section area }\end{array}$} & \multirow{2}{*}{$\begin{array}{c}\text { Fruit } \\
\text { wt } \\
(\mathrm{g})\end{array}$} & \multicolumn{2}{|c|}{$\begin{array}{c}\mathrm{C}_{2} \mathrm{H}_{4}^{\mathrm{y}} \\
\left(\mu \mathrm{mol} \cdot \mathrm{kg}^{-1} .\right. \\
\left.\mathrm{h}^{-1}\right)\end{array}$} \\
\hline & & & & Fruit & Leaves \\
\hline \multirow[t]{4}{*}{$\mathrm{BA}$} & 0 & 7.1 & 112 & 0.05 & 0.02 \\
\hline & 50 & 7.5 & 134 & 0.11 & 0.03 \\
\hline & 100 & 3.7 & 146 & 0.14 & 0.04 \\
\hline & 150 & 4.5 & 157 & 0.18 & 0.05 \\
\hline NAA & 7.5 & 2.8 & 116 & 0.10 & 0.05 \\
\hline \multicolumn{6}{|l|}{ Significance } \\
\hline $\mathrm{BA}$ & & $1^{*}$ & $1^{* * *}$ & $1 * * *$ & $1 * *$ \\
\hline NAA vs. BA & & $*$ & $* *$ & $* * *$ & NS \\
\hline NAA vs. no BA & & $* *$ & NS & $* * *$ & $* *$ \\
\hline
\end{tabular}

${ }^{2}$ Means of six observations.

${ }^{y} \mathrm{C}_{2} \mathrm{H}_{4}$ determined 1 day after treatment.

***,**,* ${ }^{\mathrm{Ns}}$ Significant at $P=0.001,0.01,0.05$, or nonsignificant, respectively.

when applied directly to the fruit (Table 4). It did not alter weight of the fruit adjacent to the treated fruit. Neither flesh firmness (64 to $66 \mathrm{~N})$ nor SSC $(10.3 \%$ to $10.6 \%)$ were affected. $\mathrm{BA}$ reduced seed count only when applied directly to the fruit.

Fruit flesh $\mathrm{Ca}$ and $\mathrm{K}$ were reduced only on treated fruit (Table $5)$. The contents of $\mathrm{Mg}(0.03 \%), \mathrm{P}_{2} \mathrm{O}_{5}(0.07 \%)$, and of $\mathrm{B}(15.3$ to $16.0 \mathrm{mg} \cdot$ liter $\left.^{-1}\right)$ were not affected.

Fruit density. Within 6 days of application, BA caused measurable abscission on spurs that originally carried three fruit (Fig. 1). The majority of abscising fruit, regardless of initial set, had dropped or the pedicels had yellowed by 12 days after 
Table 4. Effects of BA applied individually to one of two 'McIntosh' fruit on a spur on fruit set, fruit size, and fruit characteristics.

\begin{tabular}{|c|c|c|c|}
\hline \multicolumn{2}{|c|}{ BA treatment } & \multirow{2}{*}{$\begin{array}{c}\text { Fruit } \\
w^{z} \\
(\mathrm{~g}) \\
\end{array}$} & \multirow{2}{*}{$\begin{array}{l}\text { Seed } \\
\text { (no.) }\end{array}$} \\
\hline Spur & Fruit & & \\
\hline- & - & 140 & 7.1 \\
\hline - & - & 139 & 7.0 \\
\hline+ & - & 140 & 7.4 \\
\hline+ & + & 187 & 6.2 \\
\hline \multicolumn{4}{|c|}{ Significance } \\
\hline $\mathrm{Sp}$ & & $* * *$ & NS \\
\hline $\mathrm{BA}$ & & $* * *$ & $* *$ \\
\hline $\mathrm{Sp}$ & & $* * *$ & $*$ \\
\hline
\end{tabular}

${ }^{2}$ Mean of 10 observations.

***,**,*, ${ }^{\mathrm{Ns}}$ Significant at $P=0.001,0.01,0.05$, or nonsignificant, respectively.

Table 5. Effect of BA applied individually to one of two 'McIntosh' fruit on a spur on fruit nutrient content. ${ }^{2}$

\begin{tabular}{cccc}
\hline \multicolumn{2}{c}{ BA treatment } & & $\mathrm{Ca}$ \\
\hline Spur & Fruit & & $\mathrm{K}$ \\
\hline- & - & 169 & $(\%)$ \\
- & - & 164 & 0.74 \\
+ & - & 161 & 0.74 \\
+ & 129 & 0.74 \\
Significance & + & $* * *$ & 0.72 \\
Spur (BA) & & $* *$ & NS \\
Treatment & $*$ & NS \\
Spur $\times$ treatment & & $*$ \\
\hline
\end{tabular}

${ }^{7}$ Mean of ten observations

***,**,* ${ }^{\text {Ns }}$ Significant at $P=0.001,0.01,0.05$, or nonsignificant, respectively.

application. Data for final fruit set confirmed that BA caused significant thinning (Table 6), with a significant $\mathrm{BA} \times$ initial set interaction. The higher the initial set the higher the final set, regardless of the thinning treatment. However, BA reduced set more on spurs initially carrying more than one fruit. Regardless of initial set, BA appeared to completely defruit about one-third of the treated spurs (Table 7). On BA-treated spurs that originally carried more than one fruit, BA caused a nearly equal distribution of spurs bearing zero, one, or two fruit.

\section{Discussion}

The site of application can influence the response to chemical thinners. In this investigation, maximum thinning response was achieved only when BA was applied to the leaves, since comparable thinning occurred when BA was applied to the leaves only as when it was applied to both the leaves and the fruit. Similarly, Schneider (1978) reported that NAA thinned 'Golden Delicious' and 'Staymared' apples when applied to leaves, and no additional thinning was observed when both leaves and fruit were treated. The thinning response to BA differs from that of NAA, in that there was modest yet significant thinning response when BA was applied to the fruit alone, whereas NAA is ineffective when applied only to the fruit (Schneider, 1978). Carbaryl differs from both NAA and BA in that it must be applied directly to the fruit (Williams and Batjer, 1964), although mild thinning was reported when it was applied only to the spur leaves of 'Discovery' apple (Knight, 1983).

Ethylene has been implicated in the thinning response following chemical thinner application. BA treatments that caused thinning in this investigation also increased ethylene production

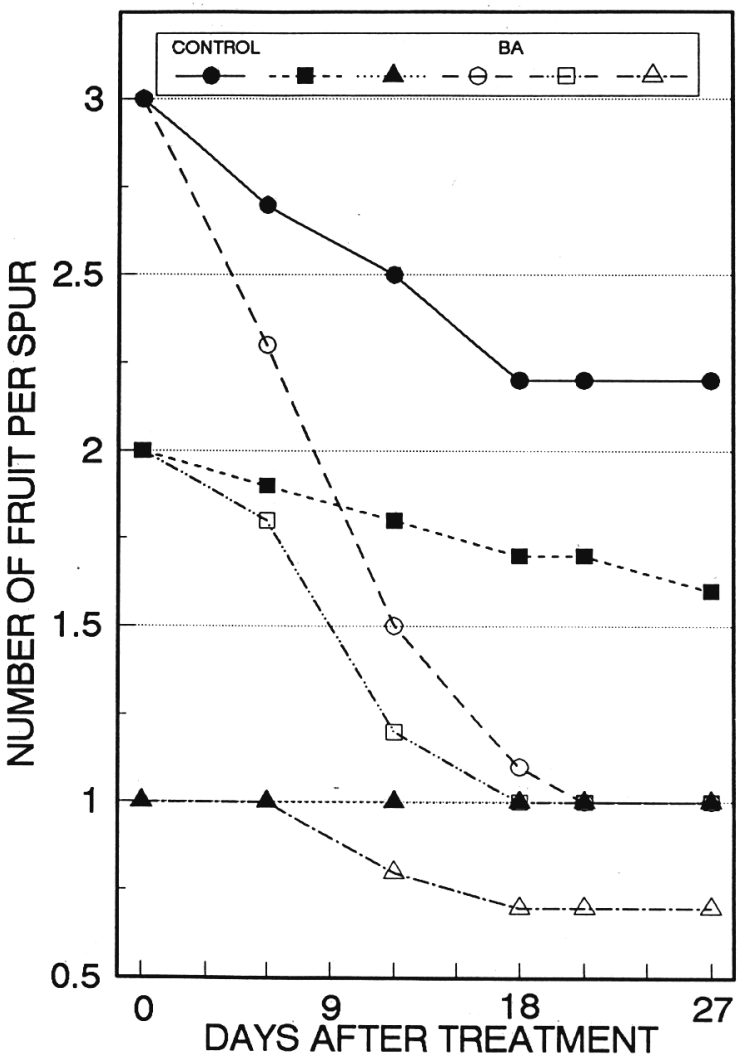

Fig. 1. Influence of initial fruit set on fruit abscission, expressed as number of fruit per spur, following BA application.

Table 6. Effect of BA (100 mg.liter $\left.{ }^{-1}\right)$ and the initial number of fruit per spur on fruit set and fruit weight of 'McIntosh'/M.9/MM.106.

\begin{tabular}{|c|c|c|c|c|c|}
\hline \multirow[b]{2}{*}{ Treatment ${ }^{z}$} & \multicolumn{2}{|c|}{$\underline{\text { Fruit per cluster }}$} & \multicolumn{3}{|c|}{ Fruit wt (g) } \\
\hline & Initial & Final & Mean & Singles & Doubles \\
\hline \multirow[t]{3}{*}{ Control } & 1 & 1.0 & 139 & 138 & $\cdots$ \\
\hline & 2 & 1.7 & 133 & 135 & 133 \\
\hline & 3 & 2.2 & 122 & 131 & 124 \\
\hline \multirow[t]{3}{*}{ BA } & 1 & 0.7 & 194 & 194 & -- \\
\hline & 2 & 1.0 & 177 & 178 & 168 \\
\hline & 3 & 1.1 & 172 & 179 & 162 \\
\hline \multicolumn{6}{|l|}{ Significance } \\
\hline \multicolumn{2}{|l|}{ BA } & $* *$ & $* *$ & $* *$ & $* *$ \\
\hline \multicolumn{2}{|l|}{ Initial set } & $* *$ & $1^{* *}$ & $1^{*}$ & NS \\
\hline \multirow{2}{*}{\multicolumn{2}{|c|}{$\begin{array}{l}\text { BA } \times \text { initial set } \\
\text { Initial set: No BA }\end{array}$}} & $* *$ & NS & NS & NS \\
\hline & & $1 * *$ & & & \\
\hline \multicolumn{2}{|c|}{ Initial set: BA } & $1^{* *}$ & & & \\
\hline
\end{tabular}

${ }^{z}$ Mean of 90 observations.

$* *,{ }^{*}{ }^{\mathrm{NS}}$ Significant at $\mathrm{P}=0.01,0.05$, or nonsignificant, respectively.

1 day after application in both leaves and fruit. This result confirms earlier reports that BA increases endogenous ethylene production (Fuchs and Lieberman, 1968; Loy and Pollard, 1981). However, we feel that BA-induced ethylene production is probably not the primary cause of thinning action by BA. Considerably higher levels of ethylene have been reported following application of NAA (Walsh et al., 1979) or ethephon (Ebert and Bangerth, 1982; Walsh et al., 1979) to 'Golden Delicious' apples. Additionally, high ethylene levels can occur without stimulating abscission (Dennis, 1987).

Fruit naturally abscise during the June drop period, presumably because of competition with other developing fruit and 
Table 7. Effect of BA and initial number of fruit per spur on percentage of spurs bearing zero to three fruit at harvest on 'McIntosh'/ M. $9 /$ MM. $106 \mathrm{x}^{2}$

\begin{tabular}{|c|c|c|c|c|c|}
\hline \multirow[t]{2}{*}{$\begin{array}{c}\text { BA } \\
\left(100 \mathrm{mg} \cdot \text { liter }^{-1}\right)\end{array}$} & \multirow[t]{2}{*}{$\begin{array}{l}\text { Initial set } \\
\text { (fruit/spur) }\end{array}$} & \multicolumn{4}{|c|}{ Final fruit per spur $(\%)$} \\
\hline & & 0 & 1 & 2 & 3 \\
\hline \multirow[t]{3}{*}{-} & 1 & 4 & 96 & -- & -- \\
\hline & 2 & 2 & 29 & 69 & --- \\
\hline & 3 & 1 & 17 & 44 & 37 \\
\hline \multirow[t]{3}{*}{+} & 1 & 34 & 66 & --- & --- \\
\hline & 2 & 32 & 36 & 32 & --- \\
\hline & 3 & 30 & 38 & 26 & 6 \\
\hline
\end{tabular}

${ }^{2}$ Means of 90 observations.

growing shoots for metabolites, including reducing sugars (Abbott, 1960; Quinlan and Preston, 1971). Postbloom sprays of NAA thinned 'Golden Delicious' apples only when applied to the leaves (Schneider, 1978). Schneider (1978) suggested that the thinning action of NAA was due to interference with photosynthate transport to the fruit since NAA reduced the amount of reducing sugars in the flesh of young fruit (Schneider and Lasheen, 1973) and reduced the transport of sugar from leaves to the developing apple fruit (Schneider, 1975). Byers et al. (1985) and Polomski et al. (1988) thinned 'Starkrimson Delicious' by either artificially shading trees or by applying the photosynthetic inhibitor terbacil, both of which lowered the reducing sugars in the fruit. The fact that BA thins primarily when applied only to the leaves indicates that it may reduce the supply of sugars to the fruit. However, it is likely that BA is thinning in another way, since Mauk et al. (1986) reported that BA enhanced rather than reduced ${ }^{14} \mathrm{C}$ assimilate export from treated leaves to developing 'Valencia' orange [Citrus sinensis (L.) Osb.] fruit.

Chemical thinners increase fruit size by lowering fruit counts, thus reducing competition for metabolites among the remaining fruit (Quinlan and Preston, 1968; Williams and Edgerton, 1981). Previous reports have suggested that BA increased fruit size more than could be attributed solely to a reduction in crop load (Greene et al., 1990; McLaughlin and Greene, 1984). We have shown conclusively in two separate experiments (Tables 1 and 4) that BA effects on fruit size are independent of the sizepromoting effect of thinning.

Fruit developing from the apical flower on a spur (king flower) are generally larger than those developing from lateral flowers. Carbaryl selectively thins within a cluster, removing the smaller lateral fruit (Knight, 1986; Way, 1967). NAA is a more potent chemical thinner than carbaryl, and nonselective thinning of spurs is frequently observed (Southwick and Weeks, 1949). BA appears to be a nonselective thinner similar to NAA.

In general, fruit set, as a percentage of initial set, is higher on trees with a light bloom than on trees with a heavy bloom (Heinicke, 1917; Williams and Edgerton, 1981). In this investigation, more fruit persisted on spurs with initially more fruit than on those with fewer, although the percentage drop was higher. This result is in agreement with those of Looney and Knight (1985) for 'Greensleeves' apple. In contrast to their report, where carbaryl was the test chemical, the number of fruit on BA-treated spurs with initially two to three fruit per spur was still higher than that from spurs carrying just one fruit.

With few exceptions, penetration of growth substances is greater through the abaxial than through the adaxial surface (Greene and Bukovac, 1971; O'Leary and Jones, 1987; Price, 1982). Field experiments done in 2 years support this result. Wang and
Rom (1987) reported that $63 \%$ of the BA applied was absorbed through the abaxial surface, while $26 \%$ was absorbed through the adaxial surface. Their values are considerably higher than those reported in this investigation. BA was relatively ineffective in inducing abscission when applied to the fruit. Since considerably more BA entered into the fruit than entered through either surface of the leaf, the lack of significant thinning can not be attributed to a lack of BA absorption by the fruit.

\section{Literature Cited}

Abbott, D.L. 1960. The bourse shoot as a factor in growth of apple fruits. Ann. Applied Biol. 48:434-438.

Byers, R.E., C.G. Lyons, K.S. Yoder, J.A. Barden, and R.W. Young. 1985. Peach and apple thinning by shading and photosynthetic inhibition. J. Hort. Sci. 60:465-472.

Dennis, E.G. 1987. Apple, p. 1-44. In: S.P Monselise (ed.). Handbook of fruit set and development. CRC Press, Boca Raton, Fla.

Ebert, A. and F. Bangerth. 1982. Possible hormonal modes of action of three apple thinning agents. Scientia Hort. 16:343-356.

Elfving, D.C. 1989. N-(phenylmethyl)-1H-purine-6-amine (BA) as a chemical thinner for 'Idared' apple. Acta Hort. 239:357-362.

Elfving, D.C. 1991. Use of BA as a chemical thinner on 'Empire' apples. Compact Fruit Tree 24:73-74.

Fuchs, Y. and M. Lieberman. 1968. Effects of kinetin, IAA, and gibberellin on ethylene production, and their interaction in growth of seedlings. Plant Physiol. 43:2029-2036.

Greene, D.W. and W.R. Autio. 1989. Evaluation of benzyladenine as a chemical thinner on 'McIntosh' apples. J. Amer. Soc. Hort. Sci. 114:68-73.

Greene, D.W., W.R. Autio, and P. Miller. 1990. Thinning activity of benzyladenine on several apple cultivars. J. Amer. Soc. Hort. Sci. 115:394-400.

Greene, D.W. and M.J. Bukovac. 1971. Factors influencing the penetration of naphthaleneacetamide into leaves of pear (Pyrus communis L.). J. Amer. Soc. Hort. Sci. 96:240-246.

Heinicke, A.J. 1917. Factors influencing the abscission of flowers and partially developed fruits of the apple (Pyrus malus L.). Cornell Univ. Agr. Sta. Bul. 393.

Jones, K.M., T.B. Koen, and R.J. Meredith. 1983. Thinning Golden Delicious apples using ethephon sprays. J. Hort. Sci. 58:381-388.

Jonkers, H. 1979. Biennial bearing in apple and pear: A literature survey. Scientia Hort. 11:303-317.

Knight, J.N. 1983. Translocation properties of carbaryl in relation to its use as an apple fruitlet thinner. J. Hort. Sci. 58:371-379.

Knight, J.N. 1986. Fruit thinning with carbaryl. Acta Hort. 179:707708.

Looney, N.E. 1986. Chemical thinning of apples: Some new strategies and important refinements to old procedures. Acta Hort. 179:597-604.

Looney, N.E. and J.N. Knight. 1985. Effects of initial set and carbaryl treatments on final fruit set of 'Greensleeves' apple. HortScience 20:400-401.

Loy, J.B. and J.E. Pollard. 1981. Interaction of ethylene and a cytokinin in promoting hypocotyl elongation in a dwarf strain of watermelon. Plant Physiol. 68:876-879.

Mauk, C.S., M.G. Bausher, and G. Yelenosky. 1986. Influence of growth regulator treatments on dry matter production, fruit abscission, and ${ }^{14} \mathrm{C}$-assimilate partitioning in citrus. J. Plant Growth Regulat. 5:111-120.

McLaughlin, J.M. and D.W. Greene. 1984. Effects of BA, $\mathrm{GA}_{4+7}$, and daminozide on fruit set, fruit quality, vegetative growth, flower initiation, and flower quality of 'Golden Delicious' apples. J. Amer. Soc. Hort. Sci. 109:34-39.

Miller, P. 1986. Apple thinning in Australia, Horticultural Research Institute, Knoxfield, Victoria Dept. of Agr. and Rural Affairs Ext. Bul. p. 1-36.

O'Leary, A.L. and A.L. Jones. 1987. Factors influencing the uptake of fenarimal and flusilazol by apple leaves. Phytopathology 77:15641568. 
Polomski, R.F., J.A. Barden, R.E. Byers, and D.D. Wolf. 1988. Apple fruit nonstructural carbohydrates and abscission as influenced by shade and terbacil. J. Amer. Soc. Hort. Sci. 113:506-511.

Price, C.E. 1982. A review of the factors influencing the penetration of pesticides through plant leaves, p. 237-252. In: D.F. Cutler, K.L. Alvin, and C.E. Price (eds.). The Plant Cuticle. Academic, New York.

Quinlan, J.D. and A.P. Preston. 1968. Effects of thinning blossoms and fruitlets on growth and cropping of Sunset apple. J. Hort. Sci. 43:373-381.

Quinlan, J.D. and A.P. Preston. 1971. The influence of shoot competition on fruit retention and cropping of apples trees. J. Hort. Sci. 46:525-534.

Schneider, G.W. 1975. ${ }^{14} \mathrm{C}$-sucrose translocation in apple. J. Amer. Soc. Hort. Sci. 100:22-24.

Schneider, G.W. 1978. Abscission mechanism studies with apple fruitlets. J. Amer. Soc. Hort. Sci. 103:455-458.

Schneider, G.W. and A.M. Lasheen. 1973. NAA and Sevin on composition, development, and abscission of apple fruit. HortScience 8:103-104.

Southwick, F.W. 1968. Chemical thinning of apples. Univ. of Massachusetts Coop. Ext. Serv. Circ. 189.
Southwick, F.W. and W.D. Weeks. 1949. Chemical thinning of apples at blossom time and up to four weeks from petal fall. Proc. Amer. Soc. Hort. Sci. 53:143-147.

Unrath, C.R. 1978. Development of ethephon's thinning potential for spur Delicious apples. Acta Hort. 80:233-243.

Walsh, C.S., H.J. Swartz, and L.J. Edgerton. 1979. Ethylene evolution in apple following post-bloom thinning sprays. HortScience 14:704-706.

Wang, R. and C.R. Rom. 1987. Effects of 6-benzyladenine on gas exchange and spur development of 'Delicious' apple. HortScience 22(5):1036 (abstr.)

Way, D.W. 1967. Carbaryl as a fruit thinning agent. II. Concentration and time of application. J. Hort. Sci. 42:355-365.

Weis, S.A., M. Drake, W.J. Bramlage, and J.H. Baker. 1980. A sensitive method for measuring changes in calcium concentration in 'McIntosh' apples demonstrated in determining effects of foliar calcium sprays. J. Amer. Soc. Hort. Sci. 105:346-349.

Williams, M.W. and L.P. Batjer. 1964. Site and mode of action of 1naphthyl N-methylcarbamate (Sevin) in thinning apples. Proc. Amer. Soc. Hort. Sci. 85:1-10.

Williams, M.W. and L.J. Edgerton. 1981. Fruit thinning of apples and pears with chemicals. U.S. Dept. Agr. Agr. Info. Bul. 289. 